\title{
CHANGES IN PATTERN OF SECOND HOME DEVELOPMENT IN COUNTRIES ARISING FROM SOCIALIST FEDERAL REPUBLIC OF YUGOSLAVIA
}

\author{
Vuk Tvrtko Opačić ${ }^{1}$ \\ Miha Koderman ${ }^{2}$
}

\begin{abstract}
Intense construction of second homes in Socialist Federal Republic of Yugoslavia (hereafter referred as ex-Yugoslavia) started in 1960's. Acquisition of second homes was affordable for wide range of ex-Yugoslav citizen population due to low prices of land and real estate, as well as favourable loan conditions from state owned banks. Motivation for ownership was different spending family holidays, which was more affordable in comparison to hotel accommodation, and investment in real estates in period of unstable ex-Yugoslav economy, represented by high inflation rates and variable currency. Predominant type of second home units was family vacation house, usually built in self-managed construction. In the moment of disintegration of common state in (and after) the year 1991, countries were at considerably different stage of development. Wars that followed even deepened the national and regional differences, which can be observed also in different second home development in new independent states. Due to private building entrepreneurship, most popular second home areas were faced with a new type of secondary residences - multi-apartment recreational buildings, often used as commercialized accommodation capacities. In the same time, prices of second homes have increased; therefore they became a privilege only for higher class. We can conclude that second home development pattern in exYugoslav countries in the last 50 years has changed from affordable to exclusive phenomenon.

From the mentioned context, the main goal of the paper arises: to compare the pattern of second home development in ex-Yugoslavia countries before and after the fall of common state. Apart from literature overview, interpretation of official available census data (1971-2011) on the national level will be given. Special emphasis on changing socio-economical context of the second home development in Croatia and Slovenia will be presented.
\end{abstract}

Keywords: second home tourism, SFR Yugoslavia, development pattern, Croatia, Slovenia

\section{INTRODUCTION}

The phenomenon of residing in second homes or weekend-houses could be traced back to the time of ancient Egypt and the Roman Empire (Coppock 1977,4; Holloway and Taylor 2006, 23; Opačić, 2012, 8), where residences such as villaerusticae or villaemaritimae were used as temporary residences by wealthier representatives of the society at the time. Today, it can be considered as one of the most popular forms of recreation among the varied sphere of leisure time activities. In most European countries this phenomenon intensified after the Second World War, when several countries registered intense construction of these dwellings.Similar development could be observed in the Socialist Federal Republic of Yugoslavia (1945-1991), whereconstruction of second homes substantially gained in popularity in 1960's. According to Gosar (1989, 165), exYugoslavia experienced an "extraordinary increase of second homes"in this period. The location of the country was marked by four distinct European physical geographical units

\footnotetext{
${ }^{1}$ Associate Professor, Department of Geography, Faculty of Science, University of Zagreb, Zagreb, Croatia.

${ }^{2}$ Assistant Professor, Department of Geography, Faculty of Humanities, University of Primorska, Koper, Croatia.
} 
(the Dinaric Alps or Dinarides, the Alps and the Pannonian and Mediterranean basins), therefore the country was characterized with a high degree of landscape diversity and became consequently attractive for second home tourism development.

The latter was generallystimulated with several political and social policies, which were introduced by the socialist government. These included affordable prices of land and real estate in general, and favourable loan conditions. As a result, self-managed building of family vacation houses increased in all six ex-Yugoslav republics until the 1980's. This phenomenon was especially evident in the Mediterranean part of the country (in littoral parts of Croatia and Montenegro), while other republics faced growth of these residences in places with significant importance for recreation and leisure activities - in mountain and lakeside resorts, as well as in the spa centres, hilly and riverside areas.However, due to the increased development of second home infrastructure in the 20th century, numerous traditional settlements faced significant transformation in terms of appearance and architecture patterns.

\section{PATTERN OF SECOND HOME DEVELOPMENT IN SOCIALIST PERIOD OF EX-YUGOSLAVIA}

Intense construction of second homes in ex-Yugoslavia started in 1960's (Jeršič, 1968;Pepeonik, 1977), when they became more acceptable phenomenon in socialist Yugoslav society. Authorities introduced the socialist self - governed model,which allowed private ownership of the (second) real estate because they wanted to provide social stability of the population. Increased motivation for acquisition of second homes in socialist Yugoslav society could be recognised as an expression of saving (Gosar, 1984; Poljanec-Borić, 1991) and investment (Gosar, 1989).In the conditions of high inflation of the local currency (the Yugoslav dinar)and the absence of a free market economy on the one hand and low land prices in depopulated rural areas (Opačić, 2012) andfavourable housing loans (Mikačić, 1994; Mikačić, 2007) on the other, investment in second homes was one of the most rational way of saving surplus capital (Opačić, 2012).The debated context was further strengthened by the fact that in the period of ex-Yugoslavia urbanoriented industry was the dominant economic activity, which initiated extensive migration flows from rural areas due to high demand for labour force.As a result, a large number of abandoned housing and commercial buildings in the villages became available at very affordable prices in many rural areas in the country (Gosar, 1989;Opačić, 2012).

In this regard, ex-Yugoslavia registered an increased interest for acquisition of second homes during the 1960's, 1970's and 1980's (Jeršič, 1968; Alfier, 1987;Klarić, 1989; Miletić, 2011; Opačić, 2012). The demand was the highest on the coast and islands especially in Croatia (Opačić, 2009b), later also in Montenegro. Mountainous areas, for example the Slovenian Alps (Gosar, 1984; 1987; Koderman, 2014a), and attractive parts of rural recreational areas of major cities (eg. in mountainous and hilly areas (Gosar, 1987; Salmič and Koderman, 2013; Koderman and Salmič, 2013), banks along rivers, lakes, etc.) in almost all parts of ex-Yugoslavia (Klarić, 1989) were also very popular for second home development. The number of second homes has grown exponentially throughout exYugoslavia and in many areas typical second home landscape has been formed. In these areas, second homes became the main factor of spatial transformation and brought 
numerous physiognomic (Opačić, 2009a), economic (Opačić, 2008), sociocultural and environmental implications in space, mostly with negative connotation (Gosar, 1987).

The development of second home phenomenon after World War II can be divided into two periods regarding the genesis of objects for rest and recreation: a) the phase of conversion and adaptation of the existing housing stock intosecond homes in areas affected by emigration and aging of the population (mostlyin 1960's and 1970's) and b) phase of construction of purposely built second homes in form of family houses (in 1970's and 1980's) (Opačić, 2009b). Regarding the morphology of the ex-Yugoslav second home dwellings, the dominant type was family detached house (Pepeonik 1983, Opačić, 2009b). The main motivation for the acquisition of second homes was relaxation and recreation of the owner and his family and friends.

The majority of second home demand came from major cities (Opačić, 2012) - a trend which coincidedwith tourism demand in general. In littoral part of Croatia, Kušen (1983) distinguished five categories of private investors from that period: a) investors from the coastal areas, which were generally not different from that from the interior part of the country, b) residents with significant personal incomes, which were previously allocated to social flats, c) workers on "temporary work abroad", whose foreign currency savings were considered a substantial capital ex-Yugoslavia, d) individual craftsmen, members of the independent professions and farmers, who were avoiding the payment of a part of their social responsibilities and taking advantage of the specific rules and privileges, which enabled them to gain a substantial financial resources and e) the category of investors that has emerged due to the large demand for real estate of the first four categories.At the end of the 1980's,the collective recreational housing was introduced in leading coastal and mountain tourism destinations of Yugoslavia. In terms of morphology of second homes this trend was manifested by multi-apartment recreational buildings, which also mark the developmental phase of second home phenomenon after the breakup of Yugoslavia and the transition to a free market economy in 1990's (Opačić, 2012).

The above mentioned trends can be clearly distinguished from Tab. 1, 2 and 3, where the number of second homes and their share in total housing stock in ex-Yugoslav republics is presented. The Federal Yugoslav bureau of statistics first started to collect the data of the so called dwellings for holiday and recreational purposes in 1971. In this year, the share of second homes in the country's total housing stock was negligible - less than one percent of the housing stock was (officially) used for second home purposes (Tab.1). One can, of course, speculate, weather such low proportion of second home residences could be attributed to the lack of methodological criteria for the mere definition of second homes, rather than actual function of this real estate in the country. Nonetheless, the most important republics in terms of second home development in the beginning of 1970's were Croatia and Montenegro, which both share a substantial and attractive coastline along the Adriatic Sea. As already mentioned above, second home development first started to develop in this littoral part of ex-Yugoslavia in particular. 
Tab. 1. Number of second homes and share of second homes in housing stock in exYugoslav republics in 1971

\begin{tabular}{|l|c|c|c|}
\hline Socialist Republic of & $\begin{array}{c}\text { Number of } \\
\text { inhabited } \\
\text { dwellings }\end{array}$ & $\begin{array}{c}\text { Number of } \\
\text { second } \\
\text { homes }\end{array}$ & $\begin{array}{c}\text { Share of second homes } \\
\text { in housing stock (\%) }\end{array}$ \\
\hline Bosnia and Herzegovina & 783,815 & 1,399 & 0.18 \\
\hline Croatia & $1,157,542$ & 22,946 & 1.98 \\
\hline Macedonia & 315,580 & 813 & 0.26 \\
\hline Montenegro & 109,202 & 1,834 & 1.68 \\
\hline Serbia & $2,107,877$ & 11,724 & 0.56 \\
\hline Slovenia & 461,225 & 4,281 & 0.93 \\
\hline ex-Yugoslavia (total) & $\mathbf{4 , 9 3 5 , 2 4 1}$ & $\mathbf{4 2 , 9 9 7}$ & $\mathbf{0 . 8 7}$ \\
\hline
\end{tabular}

Source: Federal Bureau of Statistics of the Socialist Federal Republic of Yugoslavia, 1972.

In the period between 1970 and 1980, the growth of the number of second homes in exYugoslav republics was particularly strong. Gosar (1987) stated that in this decade there was an increase in the number of individuals who not only wished to use their leisure time for engaging in recreational activities but also desired to make use of the time spent in their second homes for working in their gardens, vineyards or orchards, and this in turn led to an increase in the number of second homes being constructed in the winegrowing areas of the Pannonian and Dinaric regions.

Tab. 2. Number of second homes and share of second homes in housing stock in exYugoslav republics in 1981

\begin{tabular}{|l|c|c|c|}
\hline Socialist Republic of & $\begin{array}{c}\text { Number } \\
\text { of permanently } \\
\text { inhabited dwellings }\end{array}$ & $\begin{array}{c}\text { Number of } \\
\text { second } \\
\text { homes }\end{array}$ & $\begin{array}{c}\text { Share of second } \\
\text { homes in housing } \\
\text { stock (\%) }\end{array}$ \\
\hline Bosnia and Herzegovina & $1,015,437$ & 19,892 & 1.96 \\
\hline Croatia & $1,381,434$ & 84,317 & 6.10 \\
\hline Macedonia & 435,924 & 9,351 & 2.15 \\
\hline Montenegro & 131,472 & 11,361 & 8.64 \\
\hline Serbia & $2,579,845$ & 72,318 & 2.80 \\
\hline Slovenia & 585,780 & 18,965 & 3.24 \\
\hline ex-Yugoslavia (total) & $\mathbf{6 , 1 2 9 , 8 9 2}$ & $\mathbf{2 1 6 , 2 0 4}$ & $\mathbf{3 . 5 3}$ \\
\hline
\end{tabular}

Source: Federal Bureau of Statistics of the Socialist Federal Republic of Yugoslavia, 1984.

The described developmentcan be clearly evident from the statistical indicators, presented in Tab. 2. In this period, the strongest relativegrowthwas recorded in the republics of predominantly continental character: in Bosnia and Herzegovina, where the number of second homes grew from 1,399 in 1971 to 19,892 in 1981 (an increase of over 1400 percent), Macedonia (an increase of over 1100 percent) and in Serbia (an increase of 600 percent). Share of second homes in total housing stock also significantly increased in the other three ex-Yugoslav republics, especially in Montenegro (an increase of over 600 percent), where almost one tenth of the housing stock was dedicated for second home use (in this decade, Montenegro exceeded Croatia in the share of second homes in total 
housing stock). Secondary residences also experienced intense construction in the Alpine parts of Slovenia, where in increase of over 400 percent was recorded in the debated period.

During the 1980's, the share of second homes in housing stock doubled in almost all exYugoslav republics (the data for Bosnia and Herzegovina are not available). The increase was especially strong in Macedonia, Montenegro and Serbia, where the number of second homes grew for 272, 264 and 247 percent respectively. In Montenegro, the share of second homes presented nearly 15 percent in the total housing stock, while this share was around 10 percent in Croatia (Tab. 3).

Tab. 3. Number of second homes and share of second homes in housing stock in exYugoslav republics in 1991

\begin{tabular}{|l|c|c|c|}
\hline Republic of & $\begin{array}{c}\text { Number of } \\
\text { dwellings }\end{array}$ & $\begin{array}{c}\text { Number of } \\
\text { second } \\
\text { homes }\end{array}$ & $\begin{array}{c}\text { Share of second } \\
\text { homes in housing } \\
\text { stock (\%) }\end{array}$ \\
\hline Bosnia and Herzegovina & n. a. & n. a. & n. a. \\
\hline Croatia & $1,772,345$ & 176,845 & 9.98 \\
\hline Macedonia* & 580,342 & 25,474 & 4.39 \\
\hline Montenegro & 203,691 & 29,990 & 14.72 \\
\hline Serbia & $3,619,325$ & 179,122 & 4.95 \\
\hline Slovenia & 684,139 & 26,374 & 3.86 \\
\hline ex-Yugoslavia (total) & $\mathbf{6 , 8 5 9 , 8 4 2}$ & $\mathbf{4 3 7 , 8 0 5}$ & $\mathbf{6 . 2 8}$ \\
\hline
\end{tabular}

Sources:Bureau of Statistics of the Republic of Slovenia, 1994; Central Bureau of Statistics of the Republic of Croatia, 1995; Federal Bureau of Statistics of the Federal Republic of Yugoslavia, 1991; Statistical Office of the Republic of Macedonia, 1997.

* The data for the Republic of Macedonia are based on the year 1994.

In a relatively short period of time (1971-1991), second homes have become an important part of the ex-Yugoslav housing stock, as theirshare increased for over 700 percent over the debated period. Although the spatial distribution of second homes could be in general described as dispersed as they could be found in almost every municipality in the country, they were mostly concentrated along the coast of the Adriatic Sea and in the vicinity of larger cities, especially in the urban areas of cities Beograd and Novi Sad (this region had the highest density of second homes in ex-Yugoslavia according to Klarić $(1989,75-76))$.

In Croatia, these dwellings were predominantly located in the seaside resorts and coastal regions of the western part of Istria peninsula, in Crikvenica-Novi Vinodolski Riviera, in southern part of the Velebit coastal region (with the area of Novigrad) and in the coastal parts of Northern and Central Dalmatia (from the town of Nin to the town of Trogir, Makarska Riviera), and islands of Krk, Lošinj, Pag, Vir, Murter, Čiovo, Šolta, Brač, Hvar and Korčula. In Montenegro, second homes were similarlymost densely distributed along coastal areas, especially in the vicinity of Bay of Kotor (Klarić, 1989, 75-76; Opačić, 2009b). 


\section{PATTERN OF SECOND HOME DEVELOPMENT IN TRANSITIONAL PERIOD AFTER THE DISINTEGRATION OF EX-YUGOSLAVIA WITH SPECIAL EMPHASIS ON CROATIA AND SLOVENIA}

With the fall of socialism and the disintegration of Yugoslavia in the early 1990's, the newly formed independent states were affected by the longer (e.g. in many parts of Croatia and in Bosnia and Herzegovina) and shorter (e.g. in Slovenia) wars. Direct and indirect negative effects of wars have further slowed down economic development in most of the newly formed independent states, so the economic transition lasted longer in all countries arising from Yugoslavia (with the exception of Slovenia) than in other post-socialist European countries.

Two new processes have strongly determined the recent phase of second home development in all of the newly formed independent countries, especially in Slovenia and Croatia: a) the increased strengthening of private property and b) the emergence of private enterprise (Rogić, 2006). The main consequence of the re-inauguration of private property in the context of the second home phenomenon is the restoration of a free real estate market. The latter resulted in a significant increase of prices in the most popular tourism and second home receiving areas. The international demand for the real estate in leading second home areas in Croatia and Slovenia has grown after the opening of the real estate market to foreignersin terms of approaching and joining the European Union and was to a high degree further stimulated by significant improvement of transport infrastructure (especially the highway network) in both countries. Processes, mentioned above, have influenced second home development over the last two decades, which therefore gained different characteristics compared to the period of Yugoslavia, when it was almost exclusively based on domestic demand. However, domestic second home demand in Slovenia and Croatia still prevails in relation to foreign (Opačić, 2012; Salmič and Koderman, 2013; Koderman and Salmič, 2013; Koderman 2014b).

Although the majority of second homes in Croatia and Slovenia can still be found in the form of family homes (mostly built in the period of ex-Yugoslavia), multi-apartment recreational buildings are becoming more remarkable element of second home landscape in the coastal and island areas of Croatia, as well as in coastal and Alpine areas of Slovenia. The construction of multi-apartment recreational buildings is forced by newly established construction lobby, which in the late 1990's and early 2000's so strengthened that has often became a key participant in spatial and urban planning at the local level in the late 1990's and early 2000's.

Increase of second home real estate prices has gradually transformed this phenomenon from the wider availability of these dwellings in ex-Yugoslavia to their exclusive ownership in the newly formed independent states, where owning a second home became a privilege of higher class, i.e., a status symbol.

In Croatia and Slovenia, the leading second home areas remained the same as in the previous socialist period: the Adriatic coast, islands, mountainous areas of Slovenia (especially the Alps) and attractive parts of rural recreational areas of major cities (Miletić, 2011; Opačić, 2012; Koderman, 2014). With the appearance of the multi-apartment recreational buildings, physiognomic-functional, economic, socio-cultural and 
environmental implications of the second home phenomenon have been strengthened in manylocal communities.

While all these processes previously appeared in Slovenia and Croatia and marked their recent stage of second home development, they are now typical for other ex-Yugoslavian countries. Here, the demand for second homes still remains predominantly domestic (with the exception of the coastal area of Montenegro). The reasons for this lies in the fact that other countries are still not part of the European Union and their property market is somewhat more closed. Other important reasons for slower growth of international demand can be exposed: a longer distance of travel and weaker transport accessibility towards the main centres of second home demand, lower degree of tourism development, the presence of political tensions and instability, the unclear legislative and spatial planning framework, unregulated land registry, etc.

\section{Second home development in Croatia}

After the disintegration of Yugoslavia, Croatia has conducted two censuses of population, households and dwellings (2001 and 2011) in which second homes were registered as a part of the housing stock. In 2001, 182,513 dwellings for holiday and recreational purposes were recorded (Croatian Bureau of Statistics, 2003), while in 2011 there were 249,243 dwellings for vacation and recreation recorded (Croatian Bureau of Statistics, 2013). The number of dwellings has increased significantly over the last inter-census period (36.6\%), compared with the previous period between 1991 and 2001 (3.21\%). The reason for such intense growth lies in the increased construction of multi-apartment recreational buildings.The most prominent increase was recorded in the early 2000 's, before the economic recession which has slowed down and almost stopped the building activity in the end of the 2000's. The proportion of dwellings for holiday and recreational purposes in total housing stock has also increased - from 9.7\% in 2001 to $11.1 \%$ in 2011 (Croatian Bureau of Statistics, 2003; Croatian Bureau of Statistics, 2013).

Data from last two censuses show that the leading second home areas (according to the absolute number of dwellings for vacation and recreation, as well as according to their share in the total housing stock) have not changed. The highest number of second homes was recorded in towns and municipalities on the coast and on the islands, particularly those connected with the mainland by the bridge (e.g. Vir, Pag, Krk, etc.). In the towns and municipalities of the Northern Croatian Littoral (Istria and Kvarner regions), a higher number and higher share of second homes in the total housing stock were recorded in comparison with the Southern Croatian Littoral (Dalmatia region). The main reason for such distribution is the fact that Dalmatia is further away from the leading national and international centres of second home demand in comparison to Istria and Kvarner. Other reasonslie in the fact that Istria and Kvarner were excluded from the zone of direct war operations in the first half of the 1990's, so the development of the second home phenomenon took place more spontaneous here than in Dalmatia. In addition, because of the advantages of proximity to the centres of demand and better transport accessibility, process of construction of multi-apartment recreational buildings in the Northern Croatian Littoral began earlier and was stronger than in the Southern Croatian Littoral. Second homes make up a clear majority of the total housing fund in even 19 towns and municipalities in Croatia,with the highest share on the island of Vir (86.3\%). It is 
obviousthat the second home phenomenon in many local authority units has become a major factor of morphological and functional transformation and that its role in the Croatian littoral area further strengthens.

\section{Second home development in Slovenia}

Statistical Office of the Republic of Slovenia conducted the last "classical" census of buildings and dwellings in 2002, in which there were 31,681 second homes recorded in country. In 2011, the so called registry-based census identified only 20,740 such units. It should therefore be noted, that statistical office completed this census not by collecting data on the ground in the form of statements of owners and tenants, but by using administrative sources and integrating the data obtained from the Central Population Register of the Ministry of the Interior, the Building Cadastre and the Real-Estate Register of the Surveying and Mapping Authority and the Land Registry (managed by the Supreme Court of the Republic of Slovenia). In interpreting the data from the 2011 Census, and in possible comparisons with the previous census carried out in 2002, it should be mentioned that there may exist certain differences on account of the use of different data collection or data acquisition methods (Statistical Office of the Republic of Slovenia, 2002; 2011).

According to the census in 2002, second homes in Slovenia accounted 4.1 percent of the total housing stock. In the register-based census of 2011, their share was only 2.5 percent a decline which canmostly be attributed to the different methodology used the last census by the statistical office. Despite this fact,the municipalities with the highest proportion of second homes in their housing stock remain the same in both census years - these are the municipalitiesof Kranjska Gora, Bohinj and Bovec, all three partly located in the Triglav national park in northwestern Alpine region of Slovenia. Other, smaller municipalities (Kostel, Jezersko, Osilnica, Bloke, RibnicanaPohorju) also show a significant proportion of holiday units, however, it should be noted that these municipalities have a low number of residential units (less than 1000) in general. Although the second homes in the mentioned municipalities do not represent the dominant form of settlement as the share of permanently inhabited dwellings everywhere remains higher, secondary buildingshad a significant impact on the morphology and physiognomy of the several settlements in Slovenia.

\section{CONCLUSION}

Dramatic changes of socio-economic and political context in the countriesestablished after the dissolution of ex-Yugoslavia have significantly influenced the pattern of second homes' development. In the socialist period, when nowadays independent countries were a part of common state, main characteristics of second home development included: a) a purpose-built or converted and renovated family houses as the dominant form of second homes, b) exclusively domestic demand for acquisition of second homes, c) low prices of real estate and land, d) favourable loan conditions for the construction or renovating, and e) leisure and recreation with family and friends as the dominant pattern of the second home usage. The disintegration of the ex-Yugoslavia, with a turbulent period of wars and economic transition in 1990's, has deepened differences in economic development between ex-Yugloslavcountries, and contributed to the significant changes in the contemporary context of second home development. Therefore, the characteristics of 
recent stage of the second homedevelopment appeared earlier in Slovenia and Croatia than in other countries. The reasons lie in the earlier opening of the real estate market to foreigners (EU citizens), membership in the European Union and better transport connections with centres of second home demand. Among the main features of the recent second home development patternthe following elements can be identified: a) more pronounced presence of multi-apartment recreational buildings, especially in the leading coastal and Alpine second home areas, b) the emergence of a free real estate market and influential construction lobby, c) the emergence of international second home demand mostly in the leading coastal and Alpine second home areas, d) a strong increase in land prices, loans for purchasing second homes that are often unattainable for most citizens, e) appearance of commercial or speculative motivation on the acquisition of second homes (e. g. renting, capital investment in real estate because of the expected growth in their prices). It can be concluded that second home development pattern in the ex-Yugoslav countries in the last 50 years has changed from affordable to exclusive phenomenon.

\section{REFERENCES}

1. Alfier, D. (1987). Uzroci i posljedice pretjerane izgradnje kuća za odmor i rekreaciju na području Jugoslavije, Turizam, 35 (6), 165-171.

2. Bureau of Statistics of the Republic of Slovenia. (1994). Census of Population, Households, Dwellings and Agricultural Holdings in the Republic of Slovenia 1991: Documentation 617, Ljubljana, Bureau of Statistics of the Republic of Slovenia.

3. Coppock, J. T. (1977). Second homes: curse or blessing? Oxford, Pergamon Press.

4. Croatian Bureau of Statistics. (1995).Census of Population, Households, Dwellings and Agricultural Holdings in the Republic of Croatia 1991: Documentation 888, Zagreb, Croatian Bureau of Statistics.

5. Croatian Bureau of Statistics. (2003). Census of Population, Households and Dwellings in the Republic of Croatia 2001:http://www.dzs.hr/, Zagreb, Croatian Bureau of Statistics.

6. Croatian Bureau of Statistics. (2013). Census of Population, Households and Dwellings in the Republic of Croatia 2013:http://www.dzs.hr/, Zagreb, Croatian Bureau of Statistics.

7. Federal Bureau of Statistics of the Federal Republic of Yugoslavia. (1991). Census of Population in the Federal Republic of Yugoslavia 1991: CD, Beograd, Federal Bureau of Statistics of the Federal Republic of Yugoslavia.

8. Federal Bureau of Statistics of the Socialist Federal Republic of Yugoslavia. (1972). Census of Population and Dwellings in the Socialist Federal Republic of Yugoslavia 1971:Book 1, Beograd, Federal Bureau of Statistics of the Socialist Federal Republic of Yugoslavia.

9. Federal Bureau of Statistics of the Socialist Federal Republic of Yugoslavia. (1984). Census of Population, Households and Dwellings in the Socialist Federal Republic of Yugoslavia 1981: Table 196, Beograd, Federal Bureau of Statistics of the Socialist Federal Republic of Yugoslavia.

10. Gosar, A. (1984). Vacation cottages in the part of the Slovene Alps, Geographicalugoslavica, 5, 85-90. 
11. Gosar, A (1987). Učinki počitniških bivališčna preobrazbo slovenske kulturne pokrajine, Pokrajinski učinki človekovih dejavnosti na življensko okolje, Geographica Slovenica, 18, 183-204.

12. Gosar, A. (1989). Second homes in the Alpine region of Yugoslavia, Mountain Research and Development, 9 (2), 165-174.

13. Holloway, J. C., Taylor, N. (2006). The Business of Tourism, Harlow. New York, Financial Times Prentice Hall.

14. Jeršič, M. (1968).Sekundarna počitniška bivališča v Sloveniji in Zahodni Istri, Geografski vestnik, 40, 53-67.

15. Klarić, Z. (1989). Sekundarne rezidencije u Jugoslaviji - prostorni raspored i utjecaj na okolinu, Geografski glasnik, 51, 75-90.

16. Koderman, M., Salmič, S. (2013). Prebivati ob "jezeru bliz' Triglava": prostorska analiza počitniških bivališč v občini Bohinj, in: I. Mrak, ed., et al. Gorenjska v obdobju glokalizacije. Bled, Ljubljana: Znanstvena založba Filozofske fakultete, 111-126.

17. Koderman, M. (2014a). Razvoj počitniških bivališč v alpsko-jadranskem prostoru Slovenije, in: K. Vodeb, ed., Trajnostni razvoj turističnih destinacij alpskojadranskega prostora, Koper: Založba Univerzena Primorskem, 27-41.

18. Koderman, M. (2014b). Spatial Analysis of Second Homes in the Municipality of Piran, Academica turistica, 7 (2), 179-191.

19. Kušen, E. (1983). Izgrađena i zagrađena morska obala, Pomorski zbornik, 21, 335354.

20. Mikačić, V. (1994). Otočni turizam Hrvatske, Društvena istraživanja, 3 (4-5), $517-$ 529.

21. Mikačić, V. (2007). Utjecaj rezidencijalnog turizma na primorski prostor Hrvatske, in: Lj. Bajs et al., eds., Zbornik radova 4. hrvatskog geografskog kongresa, Zagreb: Hrvatsko geografsko društvo, 321-336.

22. Miletić, G.-M. (2011). U potrazi za drugim prostorom: sociologijski aspekti sekundarnog stanovanja u Hrvatskoj, Zagreb: Institut društvenih znanosti Ivo Pilar.

23. Opačić, V. T. (2008). Ekonomsko-geografski utjecaji i posljedice vikendaštva u receptivnim vikendaškim područjima - primjer otoka Krka, Ekonomska misao $i$ praksa, 17 (2), 127-154.

24. Opačić, V. T. (2009a). Fizionomske implikacije vikendaštva u receptivnim naseljima - primjer Malinske na otoku Krku, Geoadria, 14 (2), 273-310.

25. Opačić, V. T. (2009b). Recent characteristics of the second home phenomenon in the Croatian littoral, Hrvatski geografski glasnik, 71 (1), 33-66.

26. Opačić, V. T. (2012). Vikendaštvo u hrvatskom priobalju: jučer, danas, sutra, Zagreb: Hrvatska sveučilišna naklada.

27. Pepeonik, Z. (1977). Stanovi za odmor i rekreaciju u Jugoslaviji, Geographica Slovenica, 5, 181-194.

28. Pepeonik, Z. (1983). Prostorni raspored i osnovne značajke stambenih objekata za odmor i rekreaciju u SR Hrvatskoj, Geografski glasnik, 45, 91-103.

29. Poljanec-Borić, S. (1991). Simbolika vikendice, in S. Marković, M. Dragičević, eds., Zbornik radova, Zagreb: Institutzaturizam, 211-224.

30. Rogić, I. (2006). Odnos spram kuće za odmor u Hrvatskoj u strategiji urbanizacije 1945.-2005., Društvena istraživanja, 15 (1-2), 3-26. 
31. Salmič, S., Koderman, M. (2013). Prostorska analiza počitniških bivališč v Občini Kranjska Gora,Geografski vestnik, 85 (1), 9-24.

32. Statistical Office of the Republic of Macedonia. (1997). Census of Population, Households, Dwellings and Agricultural Holdings in the Republic of Macedonia 1994: Book XI, Skopje, Statistical Office of the Republic of Macedonia.

33. Statistical Office of the Republic of Slovenia. (2002). Census, 2002: Dwellings for leisure and recreation by number of rooms, useful floor space and type of building and total useful floor space, municipalities, Slovenia, Census 2002. Ljubljana, Statistical Office of the Republic of Slovenia.

34. Statistical Office of the Republic of Slovenia. (2011). Registry-based census, 2011: Dwellings reserved for seasonal or secondary use by type of building and number of rooms, municipalities, Slovenia, multiannually. Ljubljana, Statistical Office of the Republic of Slovenia. 